\title{
Orientation of Disk-like Particles in a Microcomposite Processing
}

\author{
YASUDA Kazunori ${ }^{*}$, OHARA Norihiro ${ }^{*}$, MORI Noriyasu ${ }^{*}$, CHIBA Kunji ${ }^{* \star}$ \\ *Department of Mechanophysics Engineering, Graduate School of Engineering, Osaka University, \\ 2-1 Yamada-Oka, Suita, Osaka, 565-0871 Japan \\ **Faculty of Education, Shiga University, 2-5-1 Hiratsu, Otsu, Shiga, 520-0862 Japan
}

Received 23 June 2004; accepted for publication 5 October 2004

\begin{abstract}
The objective of this study is to well understand the migration and orientation of thin micro-particles in a suspension flow by means of both experiments and numerical simulations. In this framework, the evolution of the orientation of thin micro-particles such as talc and mica, which were modeled by a disk-like particle, in a flow through a slit channel was analyzed to obtain the knowledge of the processing operations of thin micro-particle reinforced composites.

The thin disk-like particles were subjected by a planar extensional flow in a reservoir, then by a simple shear flow through a slit channel in the experimental apparatus used. The evolution of the orientation of thin disk-like particles was, therefore, studied in both a planar extensional and simple shear flows by numerical calculation of the Jeffery equation: thin disk-like particles aligned in a parallel orientation to upper- and lower-walls of the slit channel in a planar extensional flow through the reservoir, then entered into the inlet of the slit channel. On the other hand, in a simple shear flow through the slit channel, the disk-like particles kept this parallel orientation except the occurrence of a flip-over phenomenon. The period of the flip-over became longer with a decrease in the aspect ratio of the disk-like particles.

Furthermore, the measurements of the orientation of the talc particles in a suspension flow through the slit channel clearly showed that almost the same period of the flip-over was found although the particle size was different. These experimental results arise from complex geometries and no accurate data of the thickness of the talc particles.
\end{abstract}

Key Words: disk-like particle, talc particle suspension, orientation of thin particle, planar extensional flow, simple shear flow

\section{マイクロコンポジットの成形中におけるディスク状粒子の配向}

\author{
保田和則 ${ }^{*}$ ，小原教弘，森 教安”，千葉訓司 ${ }^{* *}$
}

\author{
1 、まえがき \\ 最近の技術の進展に伴い，マクロからナノの領域にわ \\ たる高機能性複合材料が成形され多くの分野で用いられ \\ ている. ナノコンポジットの場合には, 高分子材料にナ \\ ノオーダーの粒子を分散させることにより, 分子の構造 \\ を変えて複合材料の性能を飛躍的に向上させることが目 \\ 的である.これに対して, 強化材としてアラミッド䋐維, \\ ガラス䋐維や炭素繊維を用いたマクロな緎維強化複合材 \\ 料は，軽量で高強度，高弹性であるため工業的に広く用
}

\begin{abstract}
いられており，その特性は纎維の配向状態に大きく依存 する. 上記の二つの複合材料の中間に位置するものに雲 母あるいはタルクなどの無機粒子を強化材として使用し たマイクロコンポジットがある.この複合材料では，大 きさが 10 から数 $10 \mu \mathrm{m}$ で厚さの薄い鱗片状の粒子を熱 可塑性プラスチックへ懸濁して成形することにより，機 械的[1-8], 熱的[5,9,10]ならびに電気的特性[11]を改良す ることが目的である. 例えば，シート状のマイクロコン ポジットを考えた場合, 鱗片状の粒子が材料の厚さ方向 の中央に移動してしかも粒子がシート面に平行に配列す
\end{abstract}

** 連絡先 : 滋賀大学教育学部 520-0862 大津市平津 2-5-1, E-mail: kchiba@sue.shiga-u.ac.jp, Fax: 077-537-7840

* 大阪大学大学院工学研究科機械物理工学専攻 565-0871 吹田市山田丘 2-1 
ると, 柔軟かつ熱的, 電気的遮蔽性能の高い材料を成形 することが可能となる.

従って, 複合材料の用途に忍じてマイクロ粒子のマイ グレーションと配向をコントロールできれば用途拡大に 媻がると考えられる. 従来から, 紡系工程, シート押出 し工程や射出成形など種々の成形工程により作られた複 合材料中における雲母やタルクの配向に関しては研究が 行われているが[12], 複合材料の成形に関連した各種の流 れ中における鱗片状粒子のマイグレーションと配向に関 する基礎的なメカニズムについては, 重要ではあるが十 分には明らかにされていない.

そこで, この研究では, 鱗片状粒子の懸濁液の流れ中 における粒子のマイグレーションと配向に関する研究な らびに鱗片状粒子の懸濁液の流れに関する研究に焦点を 絞り, 実験と数值解析の両面からこの現象を明らかにす る. ここでは, 研究の第一段階として雲母あるいはタル クなどの鱗片状粒子を円板状粒子でモデル化し，シート 状複合材料の成形過程の解析を目的として, スリット流 路内での流れ中における円板状粒子の配向について調べ る. 更に, タルク粒子の懸濁液をスリット流路内で流し たときに観察される筋状の模様についても考察する．本 報では， 2 節で平面伸張流れ中および単純せん断流れ中 における円板状粒子の配向の数值解析結果について, 3 節でスリット流路内の流れ中におけるタルク粒子の配向 の観察結果について述べる. 更に, 複雑な形状のタルク 粒子の配向の変化が Jeffery の方程式を用いて表すことが できるかどうかについて考える.

\section{2. 円板状粒子の配向の数值解析}

\section{1 基礎式}

円板状粒子の場合も, 細長い粒子の場合と同様にニュ 一トン流体の homogeneous な流れ（一様な速度勾配の流 れ)中における配向の変化は次に示すJefferyの方程式[13] を用いて表すことができる.

$$
D p / D t=\omega \cdot p+\lambda(d-d: p p I) \cdot p
$$

ここで, $p$ は円板状粒子の面に立てた単位法線ベクト ルで配向ベクトルと呼ばれる．また， $\boldsymbol{d}$ は変形速度テン ソル， $\omega$ は渦度テンソル，I は単位テンソルである. $D / D t$ は物質微分で

$$
D / D t=\partial / \partial t+v \cdot \nabla
$$

であり，粒子とともに移動している観察者から見ると
(Lagrangian sense), 物質微分は $D / D t=\partial / \partial t$ となる. 更 に，入は粒子のアスペクト比（厚さ／直径） $r_{a}$ を用いて 次式で表される.

$$
\lambda=\left(r_{a}^{2}-1\right) /\left(r_{a}^{2}+1\right)
$$

なお，円板状粒子の場合には $-1<\lambda<0$ となる.

また, Jeffery の方程式は, 厳密には以下に示す仮定の 下に成立する

（1）粒子の形状は回転棈円体である.

（2）粒子が運動しても流速場は乱されない.

(3) 粒子間の干渉はない.

（4）流れは定常で，少なくとも粒子の大きさの範囲内 では homogeneous な流れである.

（5）粒子は流体と同一速度で移動する.

次に, Fig.1 に示すような座標系において, $x y$ 面内の 2 次元流れ中における粒子の 3 次元配向の変化を考える と, Jeffery の方程式は配向角 $\phi$ と $\theta$ を用いて,

$$
\begin{aligned}
& \dot{\phi}=-\omega_{z}+\lambda\left(d_{x y} \cos 2 \phi-d_{x x} \sin 2 \phi\right) \\
& \dot{\theta}=(\lambda / 2)\left(d_{x y} \sin 2 \phi+d_{x x} \cos 2 \phi\right) \sin 2 \theta
\end{aligned}
$$

と書ける.

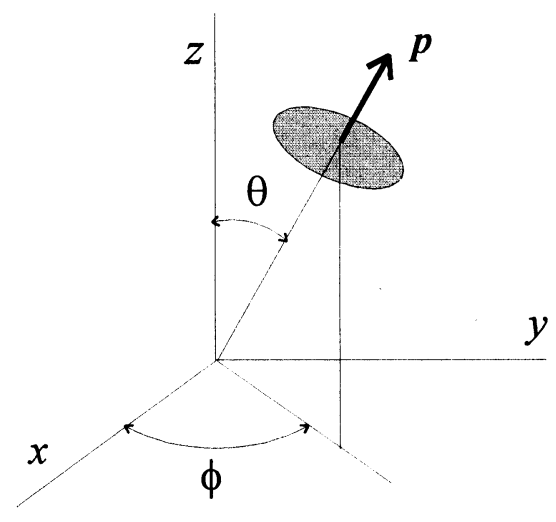

Fig.1 Disk-like particle and coordinate system.

\section{2 平面伸張流れ中および単純せん断流れ中 における円板状粒子の配向の数值解析}

スリット流路内における円板状粒子の配向の観察は, Fig.2 に示す流路で行った. スリット流路は大きなリザー バの側面に取付けられている，従って，リザーバからス リット流路へ流れ込む流れは, 中央部の広い領域でほぼ 平面伸張流れとなることが分かる（例えば, リザーバ内 
の一点鎖線で表示した面内の流れ). 更に，円板状粒子は 流線に沿って移動するので，スリット流路内の十分に発 達した流れ中では単純せん断流れに曝されることになる。 そこで, 平面伸張流れ中と単純せん断流れ中における円 板状粒子の配向の変化を調べることにした.

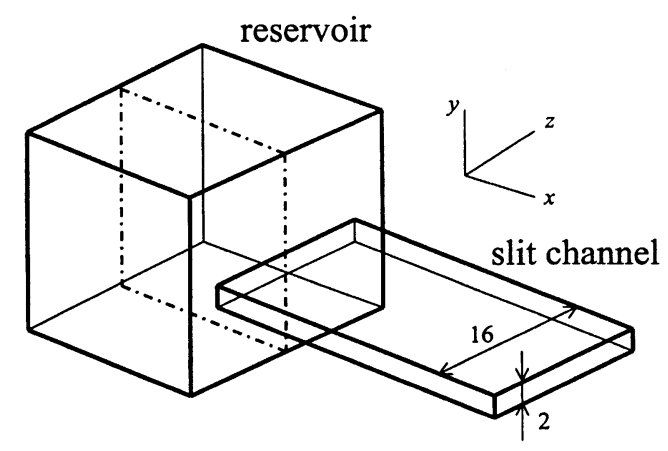

Fig.2 Schematic diagram of the reservoir and slit channel used in the experiment.

\subsection{1 平面伸張流れ中における円板状粒子の 配向の数值解析}

伸張速度を $\dot{\varepsilon}$ とすると, 流速べクトル $\boldsymbol{v}$, 変形速度テ ンソル $\boldsymbol{d}$ および渦度テンソル $\boldsymbol{\omega}$

$$
\boldsymbol{v}=\left(\begin{array}{lll}
\dot{\varepsilon} x, & -\dot{\varepsilon} y, & 0
\end{array}\right), \boldsymbol{d}=\left[\begin{array}{ccc}
\dot{\varepsilon} & 0 & 0 \\
0 & -\dot{\varepsilon} & 0 \\
0 & 0 & 0
\end{array}\right], \boldsymbol{\omega}=0
$$

となり，Jeffery の方程式(4)は

$$
\begin{aligned}
& \dot{\phi}=-\lambda \dot{\varepsilon} \sin 2 \phi \\
& \dot{\theta}=(\lambda \dot{\varepsilon} / 2) \cos 2 \phi \sin 2 \theta
\end{aligned}
$$

となる，なお，流線は $x$ 軸， $y$ 軸を漸近線とする双曲線 で表される.(6)式を 4 次の Runge-Kutta 法で数值計算し， 円板状粒子の配向に及ぼすアスペクト比, 初期角度の影 響を明らかにした。計算では，伸張速度を $\dot{\varepsilon}=1.01 / \mathrm{s}$, 初 期位置を $\left(x_{0}, y_{0}\right)=(20 \mathrm{~mm}, 20 \mathrm{~mm})$ として, アスペクト比 を $r_{a}=0.1,005,0.02$ ， 初期角度を $\phi_{0}=15^{\circ} \sim 60^{\circ}$, $\theta_{0}=10^{\circ} \sim 60^{\circ}$ と変化した.

Fig.3 に円板状粒子の配向の変化を示す. この図は円板 を $x y$ 面へ投影したもので, 中心から引かれた線分は配向 ベクトルを表している，また，単純な流れ中における細 長い粒子の配向之同様に, 円板状粒子の配向の変化も伸 張速度に関わらず伸張ひずみ $\dot{\varepsilon} t$ で決まるので, 横軸には
伸張ひずみを採っている．この図から，初期角度に関わ らず円板状粒子はその面が $x y$ 面に垂直でかつ $x$ 軸に平 行になるように配向する（配向ベクトルが $y$ 軸方向を向 く, 即ち, $\left.\phi=90^{\circ}, \theta=90^{\circ}\right)$ ことが明らかになった. ま た, Fig. 3 には $\theta_{0}=10^{\circ}$ と $60^{\circ}$ の結果のみ示すが, この配向 に到達するまでの伸張ひずみは, 初期角度 $\theta_{0}$ が大きいほ ど小さくなることも分かった。この結果から，実験に用 いた流路では，円板状粒子がリザーバからスリット流路 一流入する際に, 平面伸張流れにより円板の面をスリッ 卜流路の上下壁面にほぼ平行にして流入することが分か る.

Fig.4には, 配向角の変化に及ぼす初期角度とアスペク 卜比の影響を示す． $\phi$ は単調に増加するが（グレーの曲 線), $\phi_{0}<45^{\circ}$ の場合 $\theta$ は一旦減少した後に $90^{\circ}$ 一漸近す る. また, 初期位置での $\dot{\theta}$ の絶対值は $\theta_{0}=45^{\circ}$ のとき最大 で， $\phi_{0}$ が小さいほど大きくなることも分かる. 一方, $r_{a}=0.1,0.02$ の場合それぞれ $\lambda=-0.9802,-0.9992$ となる が，Fig.4(b)からアスペクト比が小さい方（記号で表示） が配向角の変化は大きくなるが，その差は極めて小さい ことも明らかになった. 即ち, 単純せん断流れ中と異な り, 平面伸張流れ中では配向角の変化はほとんどアスペ クト比の影響を受けないことになる。

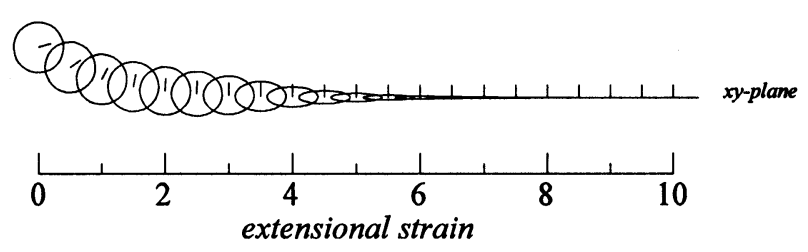

(a) initial angles $\phi_{0}=15^{\circ}, \theta_{0}=10^{\circ}$

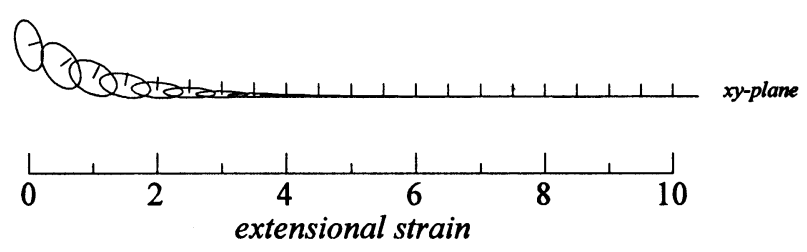

(b) initial angles $\phi_{0}=15^{\circ}, \theta_{0}=60^{\circ}$

Fig.3 Evolution of orientation of disk-like particle in a planar extensional flow for stretch rate $\dot{\varepsilon}=1 \mathrm{~s}^{-1}$, aspect ratio $r_{a}=0.1$, initial location is $(20 \mathrm{~mm}, 20 \mathrm{~mm})$.

\subsection{2 単純せん断流れ中における円板状粒子 の配向の数値解析}

せん断速度を方とすると, 流速べクトルv, 変形速度 テンソル $\boldsymbol{d}$ および渦度テンソル $\boldsymbol{\omega}$ は 


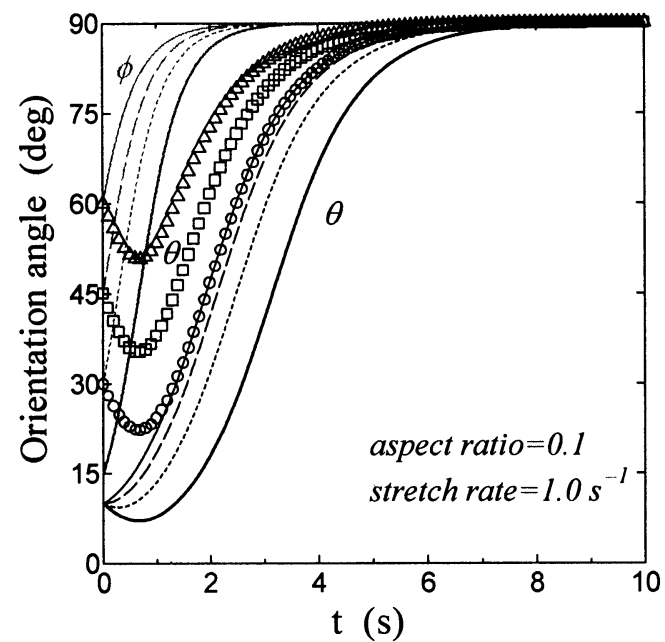

(a) effect of initial angles

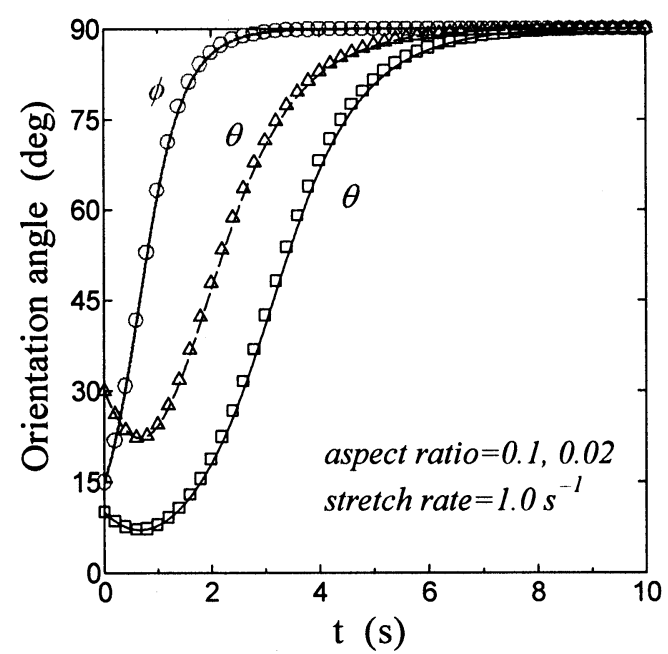

(b) effect of aspect ratio

Fig.4 Evolution of orientation angle of disk-like particle in a planar extensional flow for $\dot{\varepsilon}=1 \mathrm{~s}^{-1}$; (a) variation of $\phi$ (grey curve) for $\phi_{0}=15^{\circ}, 30^{\circ}, 45^{\circ}, 60^{\circ}$, variation of $\theta$ for $\theta_{0}=10^{\circ}, \phi_{0}=15^{\circ}$ (thick solid curve), $30^{\circ}$ (dotted curve), $45^{\circ}$ (broken curve), $60^{\circ}$ (solid curve) and variation of $\theta$ for $\phi_{0}=15^{\circ}, \theta_{0}=30^{\circ}, 45^{\circ}, 60^{\circ}$ (symbol); (b) $r_{a}=0.1$ (curve), $r_{a}=0.02$ (symbol), variation of $\phi$ (grey curve) for $\phi_{0}=15^{\circ}$, variation of $\theta$ for $\phi_{0}=15^{\circ}, \theta_{0}=10^{\circ}, 30^{\circ}$.

$$
\boldsymbol{v}=\left(\begin{array}{lll}
\dot{\gamma} y, & 0,0
\end{array}\right), \boldsymbol{d}=\left[\begin{array}{ccc}
0 & \dot{\gamma} / 2 & 0 \\
\dot{\gamma} / 2 & 0 & 0 \\
0 & 0 & 0
\end{array}\right], \omega_{z}=\dot{\gamma} / 2
$$

となり, Jeffery の方程式(4)は

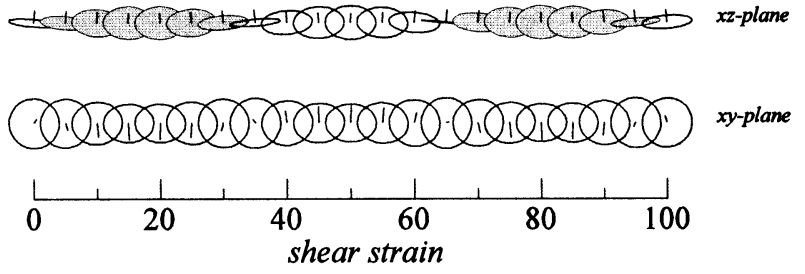

(a) aspect ratio $r_{a}=0.1$, initial angles $\phi_{0}=60^{\circ}, \theta_{0}=10^{\circ}$

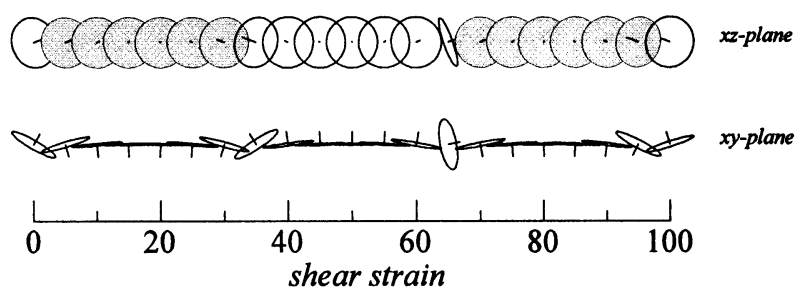

(b) aspect ratio $r_{a}=0.1$, initial angles $\phi_{0}=60^{\circ}, \theta_{0}=80^{\circ}$

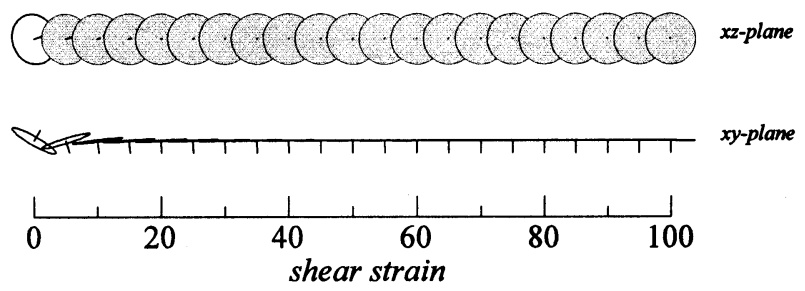

(c) aspect ratio $r_{a}=0.02$, initial angles $\phi_{0}=60^{\circ}, \theta_{0}=80^{\circ}$

Fig. 5 Evolution of orientation of disk-like particle in a simple shear flow for shear rate $\dot{\gamma}=5 \mathrm{~s}^{-1}$.

$$
\begin{aligned}
& \dot{\phi}=(\dot{\gamma} / 2)(\lambda \cos 2 \phi-1) \\
& \dot{\theta}=(\lambda \dot{\gamma} / 4) \sin 2 \phi \sin 2 \theta
\end{aligned}
$$

となる．計算では，せん断速度を $\dot{\gamma}=5.01 / \mathrm{s}, \phi_{0}=60^{\circ}$ と して，アスペクト比と初期角度を $r_{a}=0.1,005,0.02$, $\theta_{0}=10^{\circ} \sim 85^{\circ}$ と変化した.

Fig.5 では, 円板を $x y$ 面および $x z$ 面へ投影した図で円 板状粒子の配向の変化を示す. また, 円板の中心から引 かれた線分は配向ベクトルを表し, 更に, グレーの円板 は裏面が見えることを表している，なお，前項で説明し た理由により横軸にはせん断ひずみを採っている. 円板 は周期的に flip-over を起こしており，せん断ひずみの周 期は $\dot{\gamma} T=2 \pi\left(r_{a}+1 / r_{a}\right)$ となる。例えば， $r_{a}=0.1$ では $\dot{\gamma} T=63.5$ である. Figs .(b), (c)から初期角度 $\theta_{0}$ が $80^{\circ}$ と大 きい場合には， $y$ 方向から円板を観察すると（ $x z$ 面への 投影図） flip-over を起こす瞬間を除き円形に見えること が分かる. 即ち, Fig.2 に示す実験に使用したスリット流 路内で，上方から円板状粒子を観察すると flip-over を起 


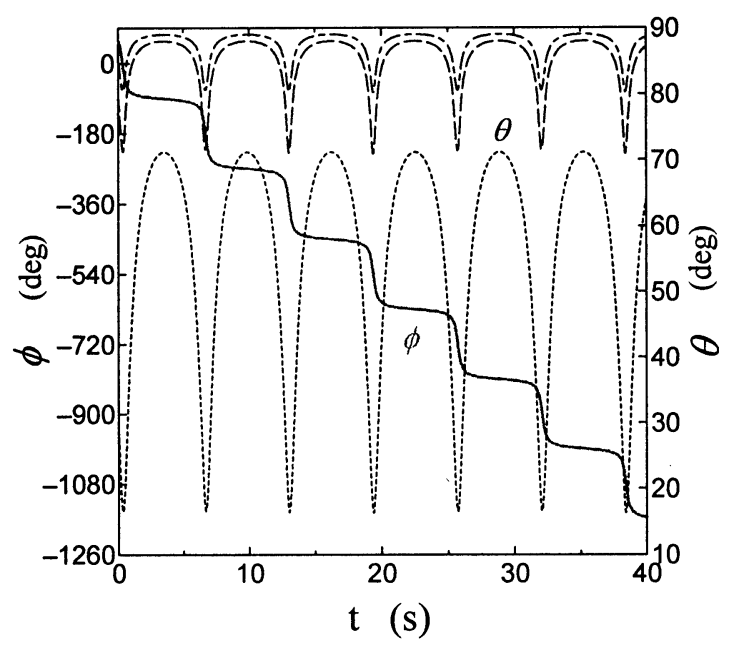

(a) effect of initial angles

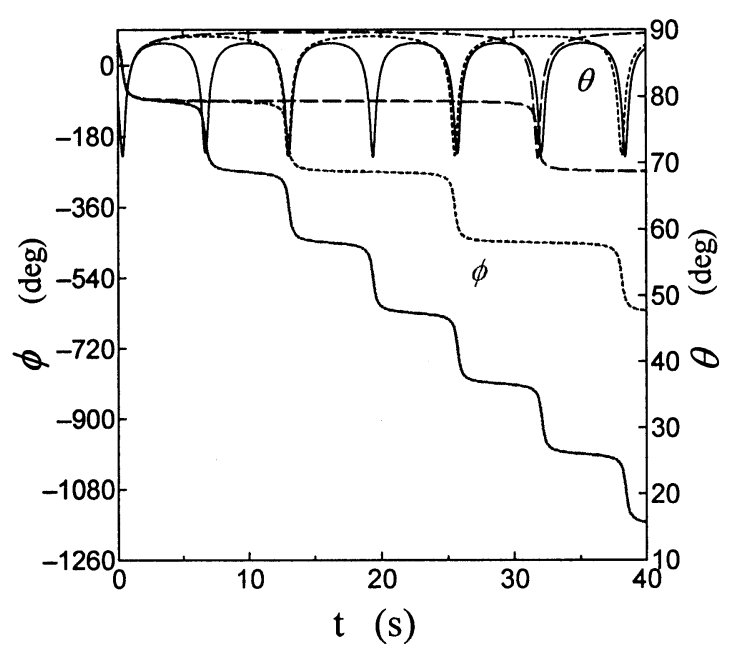

(b) effect of aspect ratio

Fig.6 Evolution of orientation angle of disk-like particle in a simple shear flow for $\dot{\gamma}=5 \mathrm{~s}^{-1}$; (a) variation of $\phi$ (grey solid curve) for $\phi_{0}=60^{\circ}$, variation of $\theta$ for $\phi_{0}=60^{\circ}$, $\theta_{0}=30^{\circ}$ (dotted curve), $80^{\circ}$ (broken curve), $85^{\circ}$ (dot-broken curve); (b) variation of $\phi$ (grey thick curve) and $\theta$ (thin curve), $r_{a}=0.1$ (solid curve), $r_{a}=0.05$ (dotted curve) and $r_{a}=0.02$ (broken curve) for $\phi_{0}=60^{\circ}, \theta_{0}=80^{\circ}$.

こしている瞬間には楕円に見えるが，ほとんどの時間円 形の形状が見られることになる．この傾向は，アスペク ト比が小さいほど flip-over の周期が長くなるので, 顕著 になる (Figs.(b),(c)).

また, 配向角の変化に及ぼす初期角度 $\theta_{0}$ とアスペクト 比 $r_{a}$ の影響を Fig.6 に示す. $\theta_{0}$ が小さいほど $\theta$ の変動振 幅は大きくなることと， $r_{a}$ が小さいほど円板状粒子の面 が $x z$ 面に平行に保たれる時間が長くなることおよび $\theta$ の変動振幅が僅かではあるが大きくなることが分かる.

\section{3.スリット流路内の流れ中における タルク粒子の配向の観察}

\section{1 実験装置および方法}

実験にはタルク粒子をグリセリンに $0.01 \mathrm{wt} \%$ 眯濁した 液体を用いた。 なお，タルク粒子の形状は様々で，比較 的円形に近いものから多角形の複雑な形状のものまであ る.大きさもまちまちで数 $\mu \mathrm{m}$ 数 $10 \mu \mathrm{m}$ の範囲にある. Fig.7 にタルク粒子の拡大写真を示す. また, 厚さは 0.5 $\mu \mathrm{m}$ 程度と言われているが確認はできない[12]. なお, 夕 ルクの密度は $\rho=2.82 \times 10^{3} \mathrm{~kg} / \mathrm{m}^{3}$ ある.

Fig.8 に実験装置概要を示す。流路は厚さ $2 \mathrm{~mm}$, 幅 16 $\mathrm{mm}$ のスリット流路である。䀣濁液はヘッドタンク内で ヘッド一定に保たれ，流量はバルブにより調節した．流 量は流路の出口で電子天秤により質量流量を測定した. また，スリット流路とバルブの間にリザーバが設けてあ る.

タルク粒子の大きさは小さいので, 透過型顕微鏡を用 いて拡大して粒子の配向の変化を $\mathrm{CCD}$ ビデオカメラに 記録した。観察位置は, 流路の幅方向の中央付近で, 厚 さ方向については壁面から中央部にかけて変化させた.

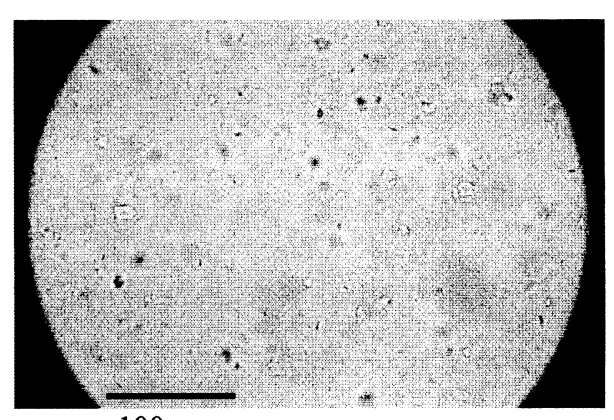

$100 \mu \mathrm{m}$

Fig.7 Microscopic view of talc particles.

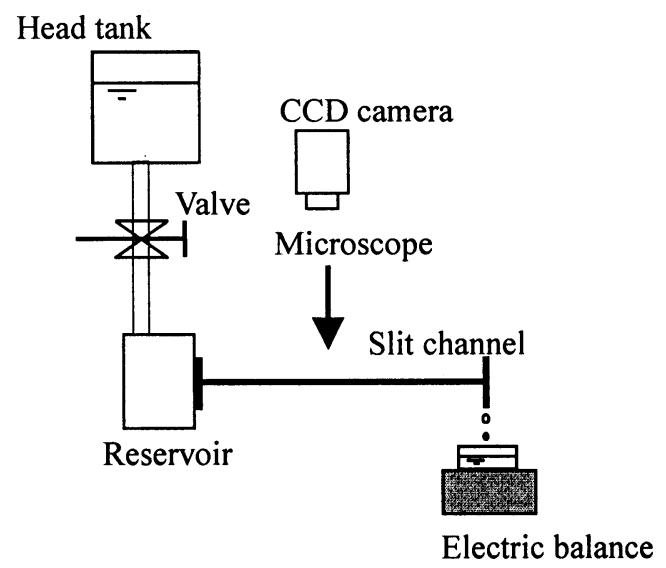

Fig.8 Schematic diagram of the experimental apparatus. 
なお，厚さ方向の位置は顕微鏡の焦点を合わせた位置 から正確に測定できる，この位置でのせん断速度は，矩 形流路内における十分に発達した流速分布の結果から計 算する．更に，タルクの形状は様々であるが，等価な円 （面積の等しい円）に換算して，タルク粒子のアスペク ト比の計算に用いることにした。このアスペクト比の值 が分かると, Jeffery の方程式から得られる粒子の flip-over の周期 $T=(2 \pi / \dot{\gamma})\left(r_{a}+1 / r_{a}\right)$ が求まり, 実験結果と比較する ことができる.

\section{2 タルク粒子の配向の変化}

Fig.9(a) (c)に, 比較的円形に近い形状から複雑な形状 まで 3 種類のタルク粒子の回転の様子を示す.これらの ビデオ画像は, flip-over している粒子の半周期の運動を 表している.

図から分かるように，大きさが大きくなるにつれて周 期が長くなるのは Jeffery の方程式から容易に想像できる また, 数值解析結果（Fig.5） と同様に, 実験においても タルク粒子は flip-overを起こしている瞬間を除き，ほと んどの時間スリット流路の上下壁面に平行に配列してい ることが分かる。しかし形状の違いによる周期性の違い も認められる. 更に, 粒子の大きさが異なるのに周期が ほぼ同じになる場合もあった. 理由としては, 複雑な形
状の扁平な粒子の場合には，円板状粒子の回転運動と大 きく異なる運動を行うことになり，形状の違いが大きく 影響することと，タルク粒子の厚さが実際には一定では なく, 粒子の大きさにより異なることなどが考えられる. しかし実際にタルクの厚さを測ることは困難であるため, 確認はできない.

また, Fig.10には, flip-over の測定周期 $T_{\mathrm{m}}$ とタルク粒 子の厚さを粒子の大きさに関わらず一定の $0.5 \mu \mathrm{m}$ とし たときの Jeffery の方程式から計算できる周期 $T_{\mathrm{J}}$ の関係を 示す．なお， $T_{\mathrm{J}}$ の值を計算する際には，タルク粒子の形 状を等価な円に換算しその直径（図中の $d$ ）を用いてい る. 粒子の大きさが増加するにつれて測定周期のばらつ きが拡大する．上述したように，これは粒子の厚さや形 状のばらつきが原因であると考えられる，なお，この図 から $T_{J} / T_{m} \approx 10$ となることが分かる. 従って, Jefferyの 方程式が適用できることを確認するためには，既知の厚 さの円板を作成して配向の変化を測定することが必要で あり，これは，今後の研究で実施する予定である.

なお，ここには図示しないが，タルク粒子の大きさに 関わらずアスペクト比を $r_{a}=1 / 15$ と一定にした場合には, $T_{J} / T_{m}$ の值は粒子の大きさに関わらず 3 程度になること も分かった. 従って, Fig.10で $T_{J} / T_{m}$ の值が大きくなっ た第一の原因としては，タルク粒子の厚さを正確に見積 れなかったことにあると考えられる.

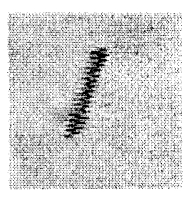

(a) $0(s)$

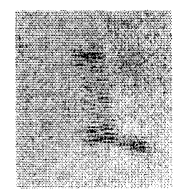

(b) $0(s)$

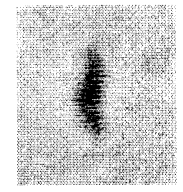

(c) $0(\mathrm{~s})$

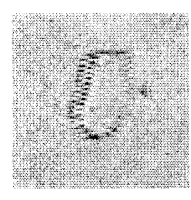

$0.4(s)$

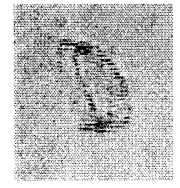

$0.4(\mathrm{~s})$

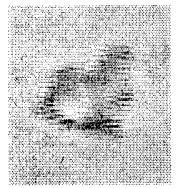

$0.5(\mathrm{~s})$

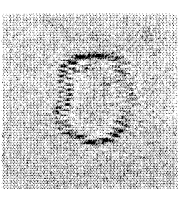

$0.8(\mathrm{~s})$

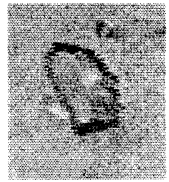

$0.8(s)$

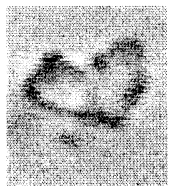

$1.0(s)$

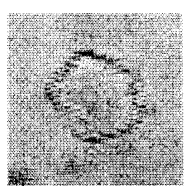

$5.0(\mathrm{~s})$

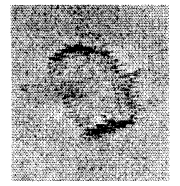

$5.0(\mathrm{~s})$

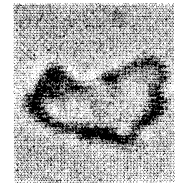

$6.0(\mathrm{~s})$

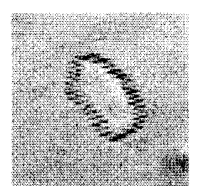

10.2(s)

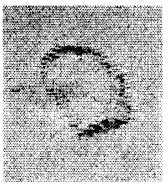

$9.0(\mathrm{~s})$

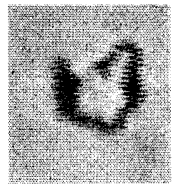

$12.3(\mathrm{~s})$

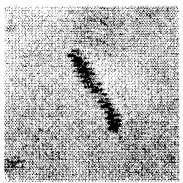

$10.6(\mathrm{~s})$

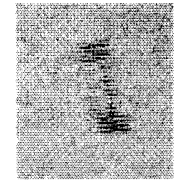

9.5(s)

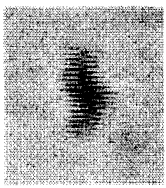

$12.8(\mathrm{~s})$

Fig.9 Evolution of talc particle rotation for (a) nearly circular shaped particle, flow rate $Q=2.57 \times 10^{-8} \mathrm{~m}^{3} / \mathrm{s}$, distance from the upper-wall $\Delta y=9.0 \times 10^{-2} \mathrm{~mm}$; (b) elliptic shaped particle, $Q=2.77 \times 10^{-8} \mathrm{~m}^{3} / \mathrm{s}, \Delta y=2.96 \times 10^{-1} \mathrm{~mm}$; (c) particle with complex geometry, $Q=2.32 \times 10^{-8} \mathrm{~m}^{3} / \mathrm{s}, \Delta y=2.82 \times 10^{-1} \mathrm{~mm}$. 


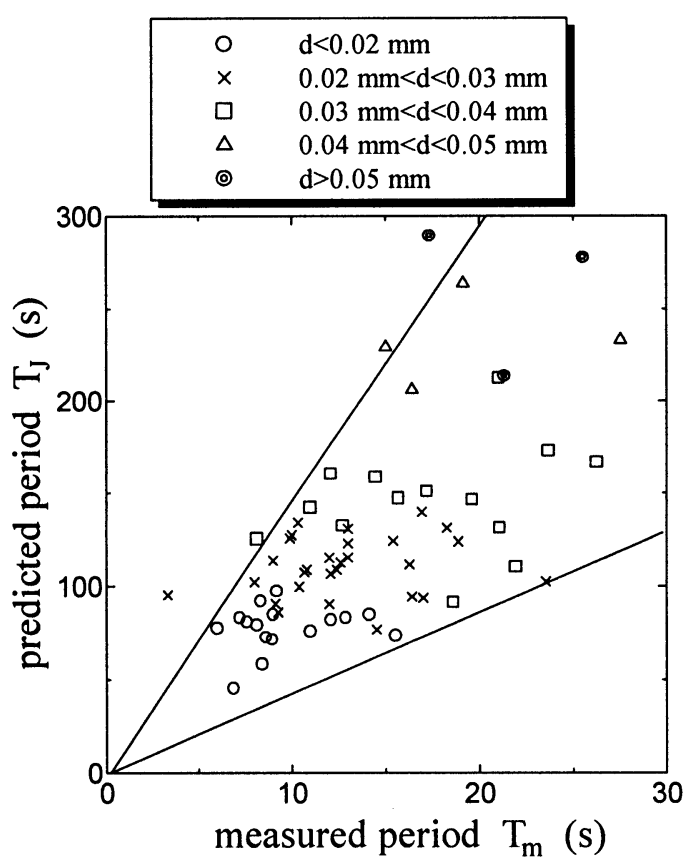

Fig.10 Relationship between the measured and predicted periods of flip-over of talc particle.

\section{3 タルク粒子懸濁液の流れにおいて観察 される模様}

Fig.11 に示すタルク粒子の懸濁液の流れにおいて観察 される 2 種類の筋状の模様について考える．２節で述べ た結果から, リザーバからスリット流路へ流入するとき, タルク粒子は面を上下壁面にほぼ平行に保っている。 ス リット流路内では, 流速は $x y$ 面内で急激に変化するが, 壁面近傍を除き流路の大部分の領域で $z$ 方向へはほとん ど変化しない. 従って, 平行平板流路内の流れと考えて よいことになる．速度勾配は上下壁面に近づくにつれて 増大するため, 壁面に近い領域を移動しているタルク粒 子は頻繁に flip-over を起こすが, 流路の中心線の近傍で は粒子はほとんど配向を変えないことになる，即ち，流 路の中心線の近傍ではタルク粒子は面を上下壁面にほぼ 平行に保ち続ける. 従って, 幅方向の透過光によって観 察した写真 Fig.(a)に現れた中心線上の筋状の模様（写真 上でははっきりとは見えにくい）は，タルク粒子の配向 状態に起因していると考えられる.

また，射出成形の金型内にはピンなどの障害物が存在 する場合がよくある．もう一つの実験では，スリット流 路の中心線上に円柱を取付けた流路内でタルク粒子懸濁 液を流した際に円柱後方に筋状の模様が観察された

(Fig.(b)). この場合円柱後方の流れは, Fig.2 に示す座標 系で $x z$ 面内の平面伸張流れで近似できる. 従って, 2.2.1 の平面伸張流れ中における円板状粒子の配向の数值計算 結果から分かるように, 円柱後方の中心線近傍ではタル
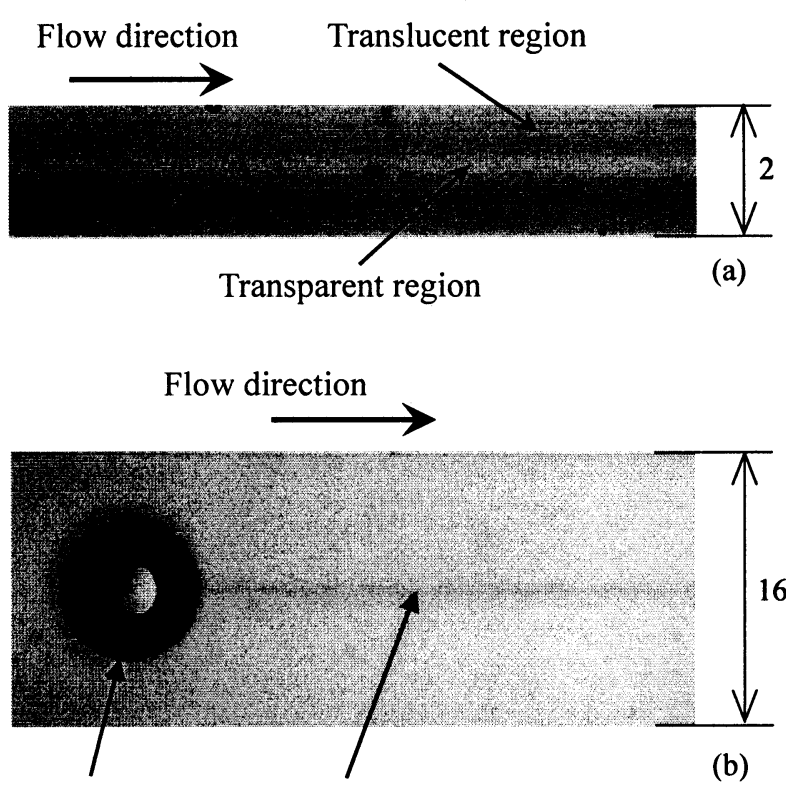

Circular obstacle Grey region

Fig.11 Flow visualizations of talc suspension; (a) side-viewed pattern through a slit channel, (b) top-viewed pattern behind a circular cylinder confined in a slit-channel, diameter of the cylinder is $8 \mathrm{~mm}$.

ク粒子は $x y$ 面に平行に配列することになる.このため周 辺の領域より幅方向に入射した光を透過しにくくなり， 筋状の模様が観察されたと考えられる.

\section{4.まとめ}

この研究の目的は, 鱗片状粒子の懸濁液の流れ中にお ける粒子のマイグレーションと配向ならびに鱗片状粒子 の懸濁液の流れを実験と数值解析の両面から明らかにす ることにある.ここでは，研究の第一段階として雲母あ るいはタルクなどの鱗片状粒子を円板状粒子でモデル化 し, シート状複合材料の成形過程の解析を目的として, スリット流路内の流れ中における円板状粒子の配向につ いて調べた.

ここで用いた実験装置では，リザーバからスリット流 路へ流れ込む流れは中央部の広い領域でほぼ平面伸張流 れとなる。 また，円板状粒子は流線に沿って移動するの で, スリット流路内の十分に発達した流れ中では単純せ ん断流れに曝される. そこで, 平面伸張流れ中と単純せ ん断流れ中における円板状粒子の配向の変化を数值解析 により調べた。 その結果, 実験に用いた流路では, 円板 状粒子がリザーバからスリット流路へ流入する際に, 平 面伸張流れにより円板の面をスリット流路の上下壁面に ほぼ平行にして流入することが分かった。このような配 向状態で流入した円板状粒子は，流路上方から観察する 
と flip-over を起こしている瞬間には楕円に見えるが，ほ とんどの時間円形の形状が観察されることになる.この 傾向はアスペクト比が小さいほど flip-over の周期が長く なるので，顕著になる.

更に, タルク粒子懸濁液のスリット流路内の流れ中に おける粒子の配向の測定から，粒子の大きさが異なるの に周期がほぼ同じになるという結果も得られた．理由と しては, 複雑な形状の扁平な粒子の場合には, 円板状粒 子の回転運動と大きく異なる運動を行い, 形状の違いが 大きく影響することと, 粒子の大きさによりタルク粒子 の厚さが異なることなどが考えられる.

\section{References}

[1] Brody, H., Ward, I.M.; Polym. Eng. Sci., 11, 139 (1971)

[2] Moghe, S.R.; Rubber Chem. Technol., 47, 1074 (1974)

[3] Goettler, L.A., Leib, R.I., Lambright, A.J.; Rubber Chem. Technol., 52, 838 (1979)
[4] Oyanagi, Y., Yamaguchi, Y., Kitagawa, M., Terao, K., Mochizuki, M.; Kobunshi Ronbunshu, 38, 285 (1981)

[5] Pipes, R.B., McCullough, R.L., Taggart, D.G; Polym. Composites, 3, 34 (1982)

[6] Maiti, S.N., Sharma, K.K.; J. Mater. Sci., 27, 4605 (1992)

[7] Karrad, S., Lopez Curesta, J.-M., Crespy, A.; J. Mater. Sci., 33, 453 (1998)

[8] McInerney, L.F., Kao, N., Bhattacharya, S.N.; Polym. Eng. Sci., 43, 1821 (2003)

[9] Nogai, T.; Sen-i Gakkaishi, 38, T-413 (1982)

[10] White, J.L., Knutsson, B.A.; Polym. Eng. Rev., 2, 71 (1982)

[11] Martinsson, J., White, J.L.; Polym. Composites, 7, 302 (1986)

[12] Lim, S.H., White, J.L.; J. Rheol., 34, 343 (1990)

[13] Jeffery, G.B.; Proc. R. Soc., A102, 161 (1922) 